\title{
Kenaf as a Bioresource for Production of Hydrogen-rich Gas
}

\author{
Yasuo Kojima ${ }^{1 *}$, Yoshiaki Kato ${ }^{1}$, Seung-Lak Yoon ${ }^{2}$ and Myong-Ku Lee ${ }^{3}$ \\ ${ }^{1}$ Department of Applied Biological Chemistry, Faculty of Agriculture, Niigata University, 2-8050 Ikarashi, Nishi-ku, Niigata, 950-2181, Japan \\ ${ }^{2}$ Department of Interior Materials Engineering, Gyeongnam National University of Science and Technology,150 Chiram-Dong, Jinju, Gyeongnam, 660-758, Korea \\ ${ }^{3}$ Department of Paper Science \& Engineering, Kangwon National University, 192-1 hyoja 2-dong, Chuncheon, 200-701, Korea
}

"Corresponding author: Yasuo Kojima, Department of Applied Biological Chemistry, Faculty of Agriculture, Niigata University, 2-8050 Ikarashi, Nishi-ku, Niigata, 950-2181, Japan, Tel: +81 (25) 262-6635; Fax: +81 (25) 262-6854; E-mail: koji@agr.niigata-u.ac.jp

Rec date: Apr 14, 2014; Acc date: Jun 16, 2014; Pub date: Jun 18, 2014

Copyright: (c) 2014 Yasuo Kojima, et al. This is an open-access article distributed under the terms of the Creative Commons Attribution License, which permits unrestricted use, distribution, and reproduction in any medium, provided the original author and source are credited.

\begin{abstract}
The two-step gasification of biomass via carbonization-step followed by steam gasification, which produces hydrogen-rich water gas without any byproducts, was achieved using a small laboratory system. Carbonization of kenaf from 600 to $1000^{\circ} \mathrm{C}$ produced suitable chars for further steam gasification, which generated clean hydrogenrich gases without any byproducts. On the other hand, carbonization of kenaf at $400^{\circ} \mathrm{C}$ yielded an insufficient char that still contained raw chemical components, and generated hydrocarbons and tar-like materials during gasification. Importantly, the wood gas generated during carbonization had a sufficient Higher Heating Value (HHV) to serve as the heating source for the gasification. A lower gasification temperature induced the water-gas shift reaction, which led to a change the hydrogen content in the water gas composition. Raising the gasification temperature increased the specific HHV and decreased the gas yield. In addition, at these gasification temperatures, the $\mathrm{H}_{2}$ concentration in the water gases was greater than $58 \%$, and the $\mathrm{H}_{2} / \mathrm{CO}$ ratio ranged from 1.8 to 3.0 . On the other hand, increasing the steam supply rate decreased the specific $\mathrm{HHV}$ and $\mathrm{CO}$ yield and increased the $\mathrm{H}_{2}$ and $\mathrm{CO}_{2}$ yields. Therefore, the water-gas shift reaction played an important role under these conditions. On the basis of all of the above results, it was concluded that the water-gas reaction, $\mathrm{C}+\mathrm{H}_{2} \mathrm{O} \rightarrow \mathrm{CO}+\mathrm{H}_{2}$, leads to effective gasification of the kenaf char
\end{abstract}

Keywords: Kenaf; Carbonization; Steam gasification; Hydrogen-rich gas

\section{Introduction}

Countries in eastern Asia and Japan, like many EU countries, have little or no reserves of good quality fossil fuels and thus must depend on imported energy. Therefore, it is in the national interest of these countries to develop alternative energy resources. The gasification of biomass (wood-based materials, agricultural residues, forestry waste, etc.) is a promising technology that provides a competitive means for producing chemicals and energy from renewable energy sources [1]. The gas mixture generated during the gasification process can be utilized in both conventional and advanced technologies for the production of electrical energy, thermal power, and as transportation fuels. Such fuels derived from biomass are environmentally favorable because they are considered to be carbon neutral $[2,3]$. Syngas which has direct application in hydro-treating operations, ammonia production, and the synthesis of methanol, dimethyl ether, and superclean liquid fuels (such as Fischer-Tropsch oil) can also be produced from gasification products $[3,4]$. Furthermore, there is growing demand for hydrogen due to its increasing use as a fuel. Currently, hydrogen gas is largely produced via the catalytic reforming of natural gas, liquefied petroleum gas, and naphtha with steam. Such a process, however, results in a significant amount of carbon dioxide emissions and thereby contributes to global warming. For this reason, alternative methods for the production of hydrogen are being investigated, including direct gasification of biomass [5,6]. A critical review of the relevant literature reveals that steam is the most widely accepted gasification agent for the production of hydrogen gas, mainly due to the quality and high yield of the generated hydrogen [7].
Progress in the field of hydrogen production from biomass has largely been hampered by technical issues associated with tar formation, which reduces the efficiency of gas production and interferes with equipment operation [8]. Formation of tar compounds generally renders the product gas mixture unsuitable for commercial applications. Therefore, numerous studies have been conducted on the elimination/destruction of tar compounds formed during biomass gasification [9-12]. Practical possibilities for tarremoval/destruction other than in-bed and multi-step methods include high mediumtemperature downstream methods that are typically based on catalytic tar cracking [13]. Processes such as hot electrostatic precipitation and adsorption by various solvents at temperatures below $400{ }^{\circ} \mathrm{C}$ are considered to be auxiliary methods [14].

Gasification generally consists of two primary steps: initial pyrolysis and subsequent char gasification. The latter is the rate-determining step that controls the overall conversion process [15]. Gasification of biomass chars has been investigated in order to gain a better understanding of char reactivity, and kinetic models have been reported using steam and carbon dioxide as gasification agents [16-20]. In addition, several studies have been reported on the gasification of biomass char from different types of biomass, e.g., grapefruit skins [21], Japanese cedar [22], sunflower shells [23], beech wood [24], slash pine [25], and bagasse [26]. Notably, Yan et al. [27] attempted to produce hydrogen-rich gas via the steam gasification of char formed as a byproduct in a fast pyrolysis liquefaction process. They concluded that both a high gasification temperature and introduction of the proper amount of steam led to a higher yield of dry gas and a higher carbon conversion efficiency. Umeki, et al. [2] also proposed that untreated char produced from high temperature steam gasification systems can be extracted from the gasifier and combusted to generate high temperature steam. 
Kenaf (Hibiscus cannabinus) is a plant in the Malvaceae family that has a high potential biomass $\left(22 \mathrm{tha}^{-1}\right)$, stem yield $\left(18 \mathrm{tha}^{-1}\right)$, and a high growth rate (180-220 $\mathrm{kg} \mathrm{ha}^{-1}$ day $\left.^{-1}\right)$ throughout the growing season [28]. In addition, in some tropical regions, kenaf can be harvested two times a year. The cuticle of kenaf, which is located on the outer parts of the shoot and is composed of long fibers, is becoming an important resource for paper production. On the other hand, the inner parts of the kenaf shoot or the core, cannot be used because of the characteristics of these tissues, and thus they are considered waste material. This material could therefore be a potential biomass source. The gasification of kenaf was reported by Zhou et al. [29], and it was determined that the gas produced from kenaf could meet the requirements for gas engines used to generate electricity; however, the gasification efficiency was insufficient, with significant ash production.

On the basis of the above information, we have proposed a tar-free gasification system using kenaf chars as the gasification source. The system consists of two reactors: carbonization furnace for char production and gasification furnace. The wood gas and char produced in the first reactor are separated, and the wood gas, including any tar, is directed to the outside of the second reactor, while the char is fed to the second reactor. The wood gas can be used as the heat source for the gasification unit in commercial plants. To develop an effective and efficient process for the production of clean hydrogen gas from biomass char using steam, various chars were prepared from kenaf, and their effects on the steam gasification as well as gasification conditions, such as the gasification temperature and steam supply rate, were investigated.

\section{Materials and Methods}

\section{Raw materials}

The kenaf was grown at a plantation located in Jollabuk-do, Korea. The matured kenaf was harvested 152 days after planting and dried in the ambient temperature for more than three months. The air dried kenaf was then debarked to obtain the kenaf core, which was cut to a length of approximately $15 \mathrm{~cm}$.

\section{Carbonization}

Two step gasification processes is illustrated in upper site of Figure 1. Preparation of the bio-char was performed by charging $400 \mathrm{~g}$ of kenaf core pieces into a stainless-steel reactor with a length of $500 \mathrm{~mm}$ and an internal diameter of $80 \mathrm{~mm}$. The reactor was heated using a cylindrical electric furnace, and the temperature was monitored using K-type thermocouples placed in the interior and on the exterior of the reactor. The reactor was heated for $180 \mathrm{~min}$ to a given temperature $\left(400,600,800\right.$, and $\left.1000^{\circ} \mathrm{C}\right)$, and then held at that temperature for 180 min. The char produced at each carbonization temperature is referred to as Char 400, Char 600, Char 800, and Char 1000, respectively. In order to obtain more reliable data, each carbonization was repeated three times, and the average of the results was used. The char yields were calculated as follows:

Char yield $(\%)=100 \times$ dried char weight $(\mathrm{g}) /$ dried kenaf weight $(\mathrm{g})$.

Wood vinegar or pyro-ligneous acid is a by-product from the charcoal production process [30]. It is a red-brown liquid generated from the gas and combustion of fresh wood burning under airless conditions. When the gas is cooled, it condenses into liquid, which contains acetic acid, methanol, acetone, wood oils and tars.
Uncondensed gas is called wood gas. These compounds are formed from decomposition of cellulose and lignin. In this study, the produced wood gases were forced through a cyclone and collected in a gas bag behind a gas flow meter with which the produced gas volumes were recorded. The major gases, including $\mathrm{H}_{2}, \mathrm{CO}, \mathrm{CH}_{4}$ and $\mathrm{CO}_{2}$ were analyzed on a gas chromatograph (J-Sciencelab GC-7000T) equipped with a packed column $(2 \mathrm{~m} \times 3.2 \mathrm{~mm}$ activated carbon $)$ and a Thermal Conductivity Detector (TCD) using argon as the carrier gas. The column oven temperature was $70^{\circ} \mathrm{C}$ and the TCD current was $90 \mathrm{~mA}$. The higher heating values (HHV) of the wood gases were calculated using the $\mathrm{HHV}$ of each gas $\left(\mathrm{H}_{2}: 12.75 \mathrm{MJ} / \mathrm{Nm}^{3}\right.$; $\mathrm{CO}: 12.63 \mathrm{MJ} / \mathrm{Nm}^{3}$; $\mathrm{CH}_{4}$ : $39.72 \mathrm{MJ} / \mathrm{Nm}^{3}$ ). Proximate analyses of the raw kenaf sample and kenaf chars were performed according to JIS M8812. Elemental analysis was conducted using an elemental analyzer (J-Sciencelab Micro-corder JM10). The structural characteristics of Char800 were observed using a scanning electron microscope (SEM, JEOL JSM-5310LV) without a conductive coating.

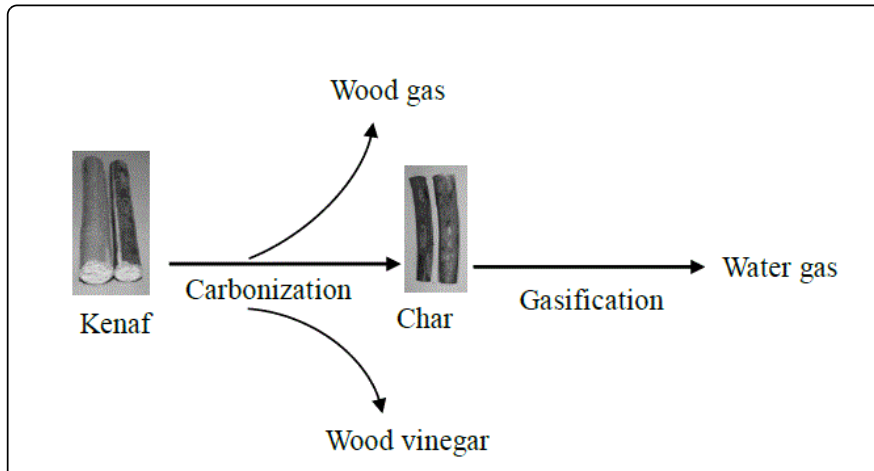

Figure 1: Process flows of carbonization and gasification.

\section{Gasification}

The prepared kenaf char was crushed and screened to obtain particle sizes from 5 to $10 \mathrm{~mm}$. A fixed bed gasifier was placed inside the electric furnace,and the char $(50 \mathrm{~g})$ was placed into the gasifier. Prior to gasification, the air in the gasifier was forced through a cyclone and then replaced with nitrogen. The gasifier reached the desired temperature at $30 \mathrm{~min}$ after heating was initiated; steam was supplied to the gasifier using a water pump. Gasification of the kenaf char was performed at 800,900 , and $1,000^{\circ} \mathrm{C}$ using a steam supply rate ranging from 0.05 to $0.15 \mathrm{~g} / \mathrm{min} / \mathrm{g}$ char. The generated gases were passed through a cyclone and a gasholder, and a gas meter was located behind the cyclone. The water gases were collected from the gasholder for measurement of the water gas composition, and the gas analysis was performed as described above for the carbonization step.

\section{Results and Discussion}

\section{Carbonization of kenaf}

The results for the carbonization of kenaf at various temperatures are listed in Table 1, and the results for the proximate and ultimate analyses of the produced kenaf chars are shown in Table 2. The yield of kenaf char decreased as the carbonization temperature increased and then leveled off at $800^{\circ} \mathrm{C}$ as shown in Figure 2. 
This tendency is similar to that reported for larch char production (indicated as the dotted line in Figure 2) [31]. The char yield and volatile matter obtained for Char400 were higher than those of the chars produced at higher temperatures due to insufficient carbonization. On the other hand, carbonization was sufficiently completed above $600^{\circ} \mathrm{C}$. This conclusion is supported by the elemental analysis results for the kenaf chars, which indicated that the volatile material and carbon content for Char600, Char800, and Char1000 were decreased notably.

\begin{tabular}{|l|l|l|l|l|l|}
\hline & & $\mathbf{C 4 0 0}$ & $\mathbf{C 6 0 0}$ & $\mathbf{C 8 0 0}$ & $\mathbf{C 1 0 0 0}$ \\
\hline $\begin{array}{l}\text { Temperature, } \\
\text { 'C }\end{array}$ & 400 & 600 & 800 & 1000 \\
\hline $\begin{array}{l}\text { Char yield, wt. } \\
\text { \% }\end{array}$ & 63.29 & 37.08 & 31.37 & 29.73 \\
\hline $\begin{array}{l}\text { Wood gas } \\
\text { yield, Nm3/kg }\end{array}$ & & 0.138 & 0.308 & 0.369 & 0.412 \\
\hline $\begin{array}{l}\text { HHV of wood } \\
\text { gas, MJ/Nm3 }\end{array}$ & 7.54 & 12.36 & 13.59 & 13.84 \\
\hline $\begin{array}{l}\text { Gas } \\
\text { composition\% }\end{array}$ & $\mathrm{H}_{2}$ & 0.00 & 19.80 & 26.80 & 30.89 \\
\hline & $\mathrm{CO}$ & 36.08 & 23.38 & 24.47 & 24.90 \\
\hline & $\mathrm{CH}_{4}$ & 2.79 & 13.41 & 13.61 & 12.81 \\
\hline & $\mathrm{CO}_{2}$ & 61.13 & 43.71 & 35.12 & 31.40 \\
\hline
\end{tabular}

Table 1: Results of carbonization of kenaf at various temperatures; ${ }^{*}$ Carbonization time was fixed at $360 \mathrm{~min}$ for all samples

\begin{tabular}{|l|l|l|l|l|l|}
\hline Sample name & kenaf & C400 & C600 & C800 & C1000 \\
\hline $\begin{array}{l}\text { Carbonization Temp., } \\
{ }^{\circ} \text { C }\end{array}$ & - & 400 & 600 & 800 & 1000 \\
\hline Volatile matter, wt.\% & 80.36 & 32.48 & 15.36 & 10.58 & 8.6 \\
\hline Fixed carbon, wt.\% & 17.21 & 63.77 & 78.16 & 81.68 & 83.12 \\
\hline Ash, wt.\% & 2.43 & 3.75 & 6.48 & 7.74 & 8.28 \\
\hline C & 42.49 & 61.71 & 86.97 & 92.86 & 94.31 \\
\hline H & 5.92 & 4.91 & 2.86 & 1.97 & 1.83 \\
\hline
\end{tabular}

Table 2: Proximate and ultimate analyses of kenaf chars

The gas from char production is referred to as wood gas and can be used as a fuel for following gasification process. Therefore, the gas yield and specific HHV of the wood gas are important factors. The yield and the specific HHV of the wood gas produced during kenaf carbonization increased with the carbonization temperature, while the gas yields were inversely proportional to the char yields. The yield and specific HHV of the wood gas obtained at each carbonization temperature are shown in Figure 3. Carbonization at $400^{\circ} \mathrm{C}$ resulted in a significantly low specific $\mathrm{HHV}$ due to the low $\mathrm{CH}_{4}$ content in the wood gas as compared with that in the wood gases obtained at higher carbonization temperatures.

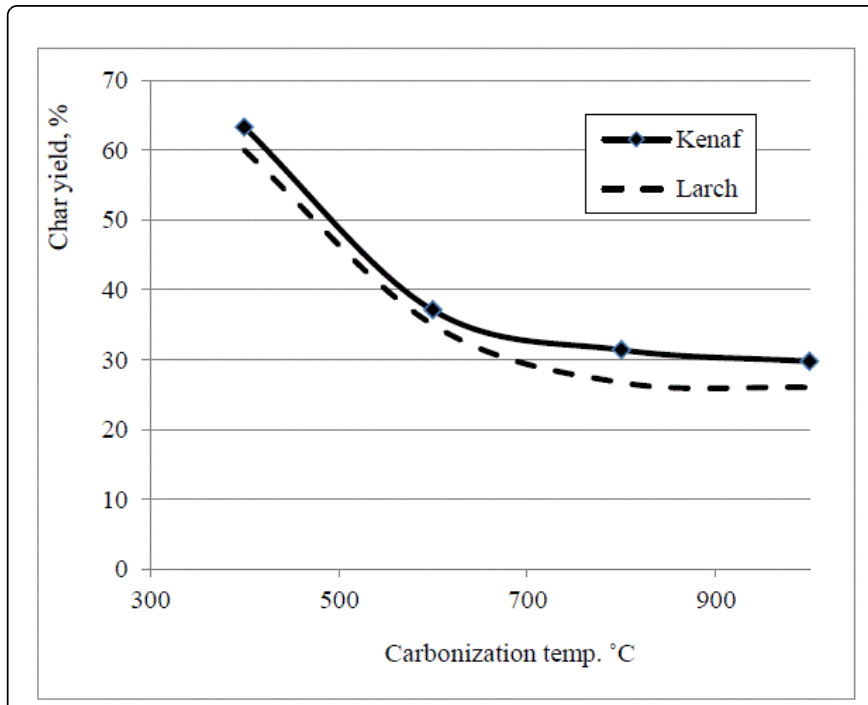

Figure 2: Yields of kenaf chars from different carbonization temperatures

The specific HHV depended on the wood gas composition; $\mathrm{CH}_{4}$ has a higher caloric value than $\mathrm{H}_{2}$ and $\mathrm{CO}$. Generally, pyrolysis of biomass, such as via gasification and carbonization, initially generates tar as a byproduct that, under high temperature conditions, is then decomposed to hydrocarbons [13]. Thus, during the carbonization of kenaf at $400^{\circ} \mathrm{C}$, it was concluded that decomposition of the tar did not occur, resulting in the low $\mathrm{CH}_{4}$ content in the produced wood gas. It means that carbonization of kenaf at $400^{\circ} \mathrm{C}$ remained tar in the kenaf char, and did not provided the suitable char for gasification. Interestingly, raising the carbonization temperature led to an increase in the $\mathrm{CO}$ and $\mathrm{H}_{2}$ content, as well as the $\mathrm{CH}_{4}$ content, while $\mathrm{CO}_{2}$ production leveled off above $600^{\circ} \mathrm{C}$.

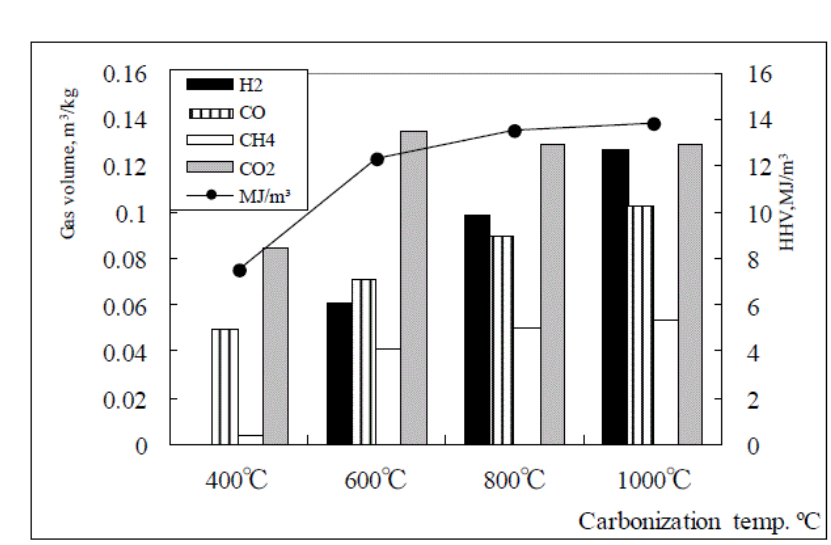

Figure 3: Wood gas composition and $\mathrm{HHV}$ produced from different carbonization temperature

The structural characteristics of the kenaf char are shown in Figure 4. A photograph of the kenaf before debarking can be seen (left) next to an image of the Char800 sample (right) in Figure 4a. This comparison confirms that the kenaf was indeed cracked during the carbonization process and carbonized completely. Figures $4 \mathrm{~b}$ and 
Citation: Kojima Y, Kato Y, Yoon SL, Lee MK (2014) Kenaf as a Bioresource for Production of Hydrogen-rich Gas. Agrotechnol 3: 1000125. doi:

Page 4 of 8

Figure $4 \mathrm{c}$ are low and high magnification transverse section SEM images of Char800, respectively. Interestingly, the tissue structure of Char800 remained the same as that in the original kenaf, and the parenchymatous pith (left) and woody tissues (right) can be observed (Figure $4 \mathrm{~b}$ ). In addition, vessel members with small pits can be seen (Figure 4c). A more detailed observation was previously reported by Voulgaridis, et al. [32].

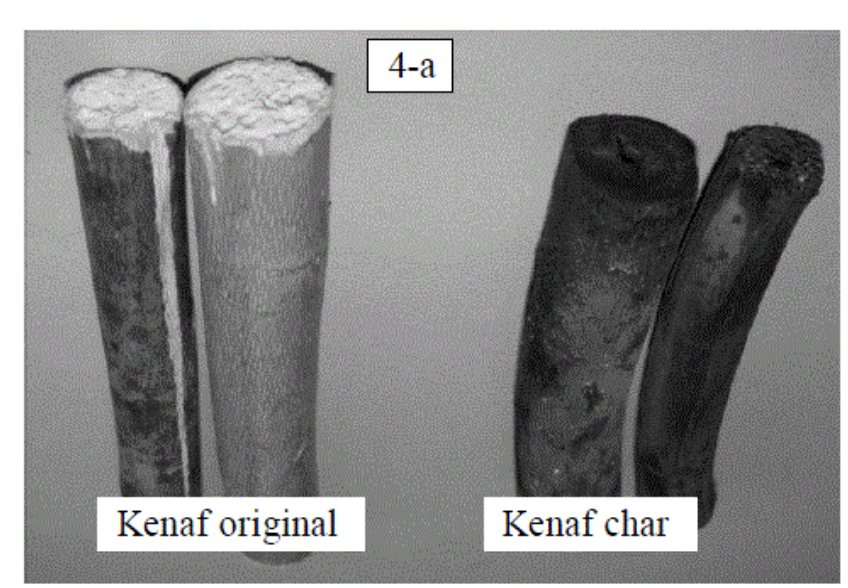

Figure 4a: Photographs of kenaf and kenaf chars

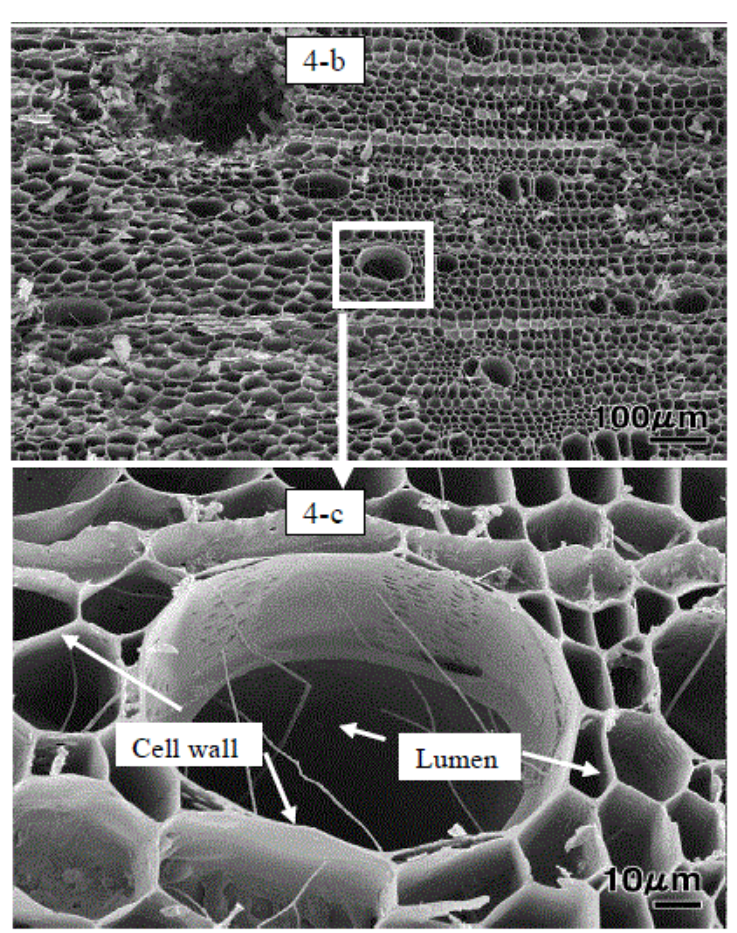

Figure 4b: SEM of kenaf char in low magnitude and 4c: High magnitude SEM of $4 \mathrm{~b}$

\section{Gasification of the kenaf char}

During gasification of the char with steam, clean fuel gases with high caloric value were produced. The final gas composition and HHV is the result of the combination of a series of complex and competing reactions shown as follows:

1) Water-gas reaction: $\mathrm{C}+\mathrm{H}_{2} \mathrm{O} \rightarrow \mathrm{CO}+\mathrm{H}_{2}$

2) Boudouard reaction: $\mathrm{C}+\mathrm{CO}_{2} \rightarrow 2 \mathrm{CO}$

3) Water-gas shift reaction: $\mathrm{CO}+\mathrm{H}_{2} \mathrm{O} \rightarrow \mathrm{CO}_{2}+\mathrm{H}_{2}$

The water-gas reaction is a solid-gas heterogeneous reaction; thus, the reaction mechanism should be more complex. We proposed formation mechanism of $\mathrm{H}$ and $\mathrm{CO}$ for char with steam via the watergas reaction is $5 \mathrm{C}+5 \mathrm{H}_{2} \mathrm{O} \rightarrow 5 \mathrm{CO}+5 \mathrm{H}_{2}$ (not including the initial release of $4 \mathrm{H}$ radicals from the char), as illustrated in Figure 5. Char is a Hydrocarbons (PAHs), chemical structure showed in Figure 5 have been used as a structure model of char surface.<smiles>Cc1cc2c(c(C)c1C)C(=O)c1c(C)cc(C(C)C)c(C)c1C2=O</smiles>

Figure 5: Proposed water gasification pathways

In the first step, $\mathrm{H}$ radicals are released from the char surface of the bio-char, and the remaining surface carbon radicals act as $\mathrm{OH}$ radical acceptors, resulting in the formation of $-\mathrm{C}-\mathrm{O}-\mathrm{H}$ structures at the char surface. A second release of $\mathrm{H}$ radicals from the $-\mathrm{C}-\mathrm{O}-\mathrm{H}$ groups leads to the generation of carbonyl compounds. Electron transfer then occurs at the adjacent $\mathrm{C}-\mathrm{C}$ bonds, and $\mathrm{CO}$ gas is formed. The chain reaction then continues on the char surface in the presence of $\mathrm{H}_{2} \mathrm{O}$. In this steam gasification process, hypothetical transport route of steam and generated gas is proposed that the steam first diffuses into the lumen (intracellular space), and then gasification proceeds in the cell wall. The generated gases are then released to the lumen and spread to the exterior of the cell wall (Figure 4).

\section{Effect of gasification temperature on the gas yield, $\mathrm{HHV}$, and gas composition}

The results of the steam gasification of the kenaf chars are listed in Table 3, and the effect of the gasification temperature and char preparation temperature on the specific HHV are shown in Figure 6. The gasification of Char400 produced water gas with a high specific $\mathrm{HHV}$ at all gasification temperatures due to the high $\mathrm{CH}_{4}$ content of the water gas. However, the Char400 sample contained chemical 
Page 5 of 8

\begin{tabular}{|c|c|c|c|c|c|c|c|c|c|c|c|c|}
\hline \multirow{2}{*}{$\begin{array}{l}\text { Sample name } \\
\text { Gasification temp. } \\
{ }^{\circ} \mathrm{C}\end{array}$} & \multicolumn{3}{|l|}{ C400 } & \multicolumn{3}{|l|}{ C600 } & \multicolumn{3}{|l|}{ C800 } & \multicolumn{3}{|l|}{ C1000 } \\
\hline & 800 & 900 & 1000 & 800 & 900 & 1000 & 800 & 900 & 1000 & 800 & 900 & 1000 \\
\hline $\begin{array}{l}\mathrm{HHV} \text { of water gas } \\
\mathrm{MJ} / \mathrm{m} 3\end{array}$ & 12.12 & 13.39 & 13.31 & 11.74 & 13.09 & 13.31 & 11.55 & 13.07 & 13.58 & 10.69 & 12.72 & 13.05 \\
\hline $\begin{array}{l}\text { Total gas yield } \\
\mathrm{m} 3 / \mathrm{kg} \text { of kenaf } \\
\text { char }\end{array}$ & 3.06 & 3.20 & 3.33 & 5.11 & 4.92 & 4.72 & 5.43 & 4.83 & 4.91 & 6.21 & 6.13 & 6.06 \\
\hline $\mathbf{H}_{2}$ & 1.81 & 1.80 & 1.92 & 3.23 & 2.83 & 2.79 & 3.37 & 2.75 & 2.80 & 3.90 & 3.22 & 2.92 \\
\hline co & 0.59 & 0.94 & 0.95 & 0.96 & 1.50 & 1.55 & 1.12 & 1.60 & 1.66 & 1.14 & 1.60 & 1.49 \\
\hline $\mathrm{CH}_{4}$ & 0.07 & 0.08 & 0.07 & 0.04 & 0.03 & 0.00 & 0.00 & 0.00 & 0.00 & 0.00 & 0.00 & 0.00 \\
\hline $\mathrm{CO}_{2}$ & 0.57 & 0.39 & 0.40 & 0.87 & 0.56 & 0.38 & 0.94 & 0.49 & 0.32 & 1.42 & 0.62 & 0.45 \\
\hline
\end{tabular}

Table 3: Properties of water gas from kenaf chars; ${ }^{*}$ Steam supply rate; $0.05 \mathrm{ml} / \mathrm{min} / \mathrm{g}$

components of the kenaf raw material in its char structure due to insufficient carbonization.

These intact chemical components, such as carbohydrates and lignin, produced the $\mathrm{CH}_{4}$ along with tar during the gasification process. While the tar was not analyzed quantitatively, a small amount of tar-like substance was detected inside the pipe system and the cyclone after gasification of Char400. On the other hand, gasification of Char1000 yielded water gas with a low specific HHV due to the high content of $\mathrm{CO}_{2}$. Water gas produced from steam gasification of Char600 and Char800 showed intermediate HHV values between those obtained for Char400 and Char1000. In addition, the gasification temperature had a significant effect on the specific HHV of the water gas produced from the kenaf chars; the results were noticeably different when the gasification temperature was increased from 800 to $900{ }^{\circ} \mathrm{C}$. No significant effect on the specific HHV, however, was observed when the gasification temperature was raised from 900 to $1000{ }^{\circ} \mathrm{C}$. In this temperature range, it seems that gasification reaction (1-3) was occurred in same degree.

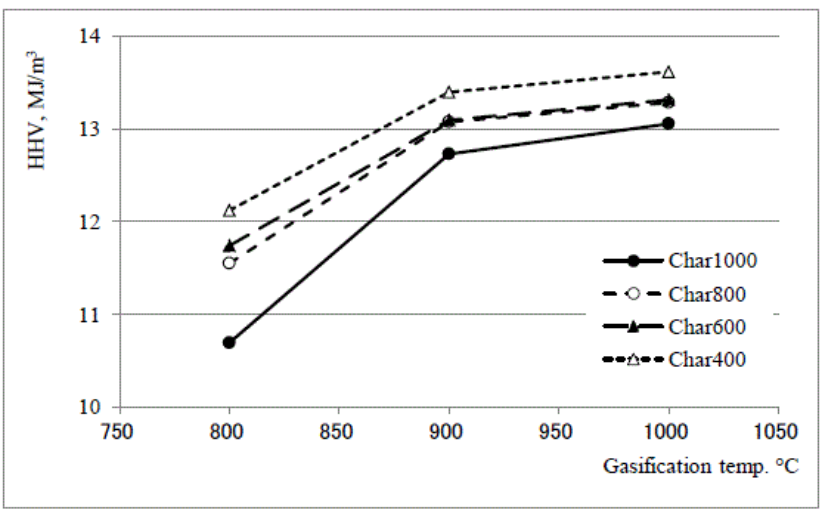

Figure 6: Effect of the char preparation temperature and the gasification temperature on gas production (steam supply rate 0.05 $\mathrm{g} / \mathrm{min} / \mathrm{g}$ )
The effects of the gasification temperature and char preparation temperature on the water gas yield are shown in Figure 7. Notably, the gasification temperature did not have a significant effect on the gas yield; the gas yield from Char400 only slightly increased, while the gas yield from Char600 and Char800 slightly decreased when the gasification temperature was increased. On the other hand, the char preparation temperatures had a significant effect on the water gas yield. The gas yield from Char400 was low despite its high volatile matter content. As mentioned above, this volatile material was converted to a tar-like substance during the gasification process, while the fixed carbon reacted with steam to form the water gas. The gas yield from Char1000 was approximately two times that from Char400, and was slightly higher than those fromChar600 and Char800, which were 1.8 times that from Char400. Thus, the gas yield, as well as the specific HHV, depends on the char microstructure, such as the specific surface area and the pore volume of the char, which influences the reaction of the steam with the char.

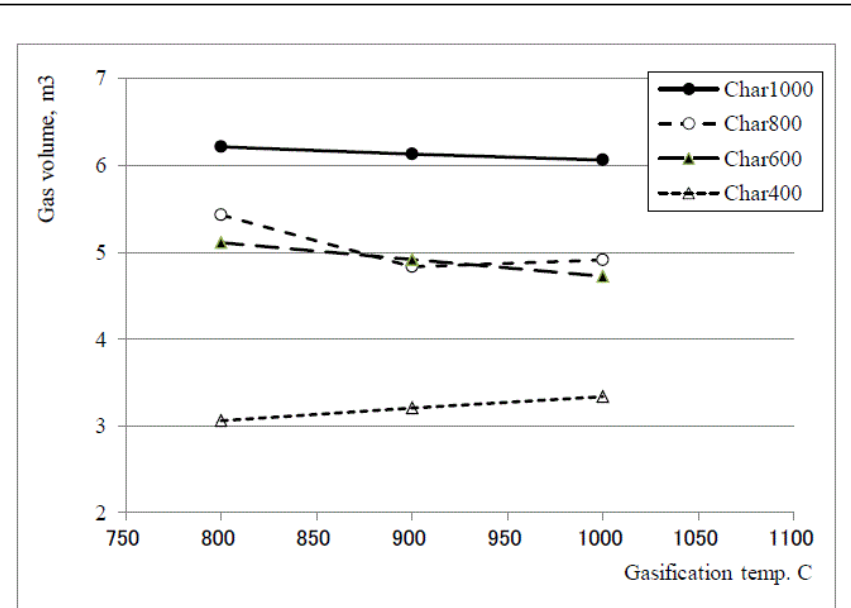

Figure 7: Effect of the char preparation temperature and the gasification temperature on gas production (steam supply rate 0.05 $\mathrm{g} / \mathrm{min} / \mathrm{g}$ ) 
The gasification of all of the kenaf chars proceeded in a similar manner, and the gas compositions produced from Char600, Char800, and Char 1000 were also similar. Gasification of Char400 was complex because it involved both char gasification and biomass gasification. Therefore, the composition of the gas generated from gasification of Char400 contained hydrocarbons, such as methane, and tar-like substances that were not detectable by GC-TCD. The gas composition from the gasification of Char800 as a representative sample is shown in Figure 8. The gasification of Char 800 at $800^{\circ} \mathrm{C}$ yielded higher amounts of $\mathrm{H}_{2}$ and $\mathrm{CO}_{2}$ and a lower $\mathrm{CO}$ content than that at 900 and $1000^{\circ} \mathrm{C}$. This result suggests that gasification at $800^{\circ} \mathrm{C}$ accelerated the water-gas shift reaction because it is an exothermic reaction and dominant at the lower gasification temperatures used in this study. In the water-gas shift reaction, two moles of gas $\left(\mathrm{H}_{2}\right.$ and $\left.\mathrm{CO}_{2}\right)$ are produced from one mole of gas (CO), and the relative specific $\mathrm{HHV}$ is reduced by the additional $\mathrm{CO}_{2}$ production. During gasification of the kenaf char, the generated water gases were obtained without the formation of tar or other byproducts. This phenomenon is attributed to the absence of compounds including hydrogen and oxygen in the char structure.

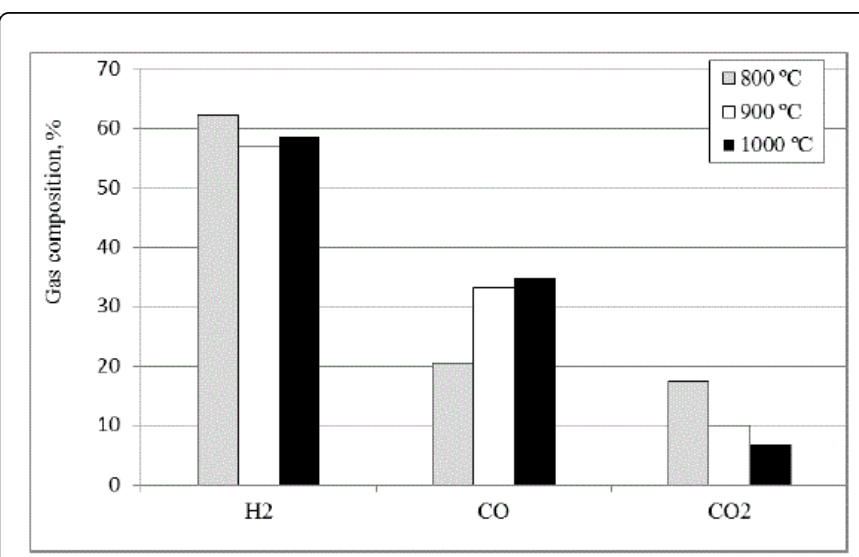

Figure 8: Effect of gasification temperature on gas production (\% and volume): Char800, steam supply rate $0.05 \mathrm{~g} / \mathrm{min} / \mathrm{g}$

The $\mathrm{H}_{2} / \mathrm{CO}$ and $\mathrm{CO} / \mathrm{CO}_{2}$ ratios in the gas mixture produced from Char800 are shown in Figure 9. The highest $\mathrm{H}_{2} / \mathrm{CO}$ ratio was obtained for the gasification at $800^{\circ} \mathrm{C}$, while the gasification processes at $900^{\circ} \mathrm{C}$ and $1000^{\circ} \mathrm{C}$ yielded the same $\mathrm{H}_{2} / \mathrm{CO}$ ratio. On the other hand, the lowest $\mathrm{CO} / \mathrm{CO}_{2}$ ratio was observed for the gasification at $800^{\circ} \mathrm{C}$, and this ratio increased with the gasification temperature.

\section{Effect of the steam supply on the gas yield, HHV, and gas composition}

The results for the gasification of Char 800 at $900^{\circ} \mathrm{C}$ at various steam supply rates $(0.05$ to $0.15 \mathrm{~g} / \mathrm{min} / \mathrm{g}$ char) are listed in Table 4 . The specific $\mathrm{HHV}$ and gas yield decreased as the rate of the steam supply increased. The yields of $\mathrm{H}_{2}$ and $\mathrm{CO}_{2}$, however, increased with the steam supply rate, while the $\mathrm{CO}$ yield decreased, as shown in Figure 10. These results suggest that the increase in the steam concentration in the gasifier that occurs when the steam supply rate is increased leads to acceleration of the water-gas shift reaction. Furthermore, increasing the steam supply led to a reduction in the gasification temperature. Yan, et al. [27] reported that increasing the steam flow rate decreased the $\mathrm{CO}$ yield and increased the $\mathrm{H}_{2}$ and $\mathrm{CO}_{2}$ yields in the gasification of char produced from fast pyrolysis liquefaction.

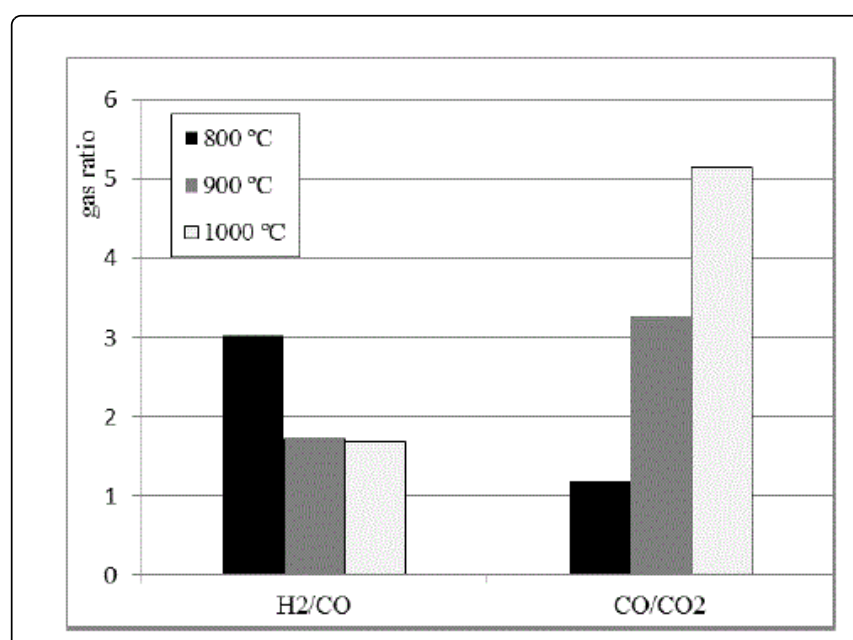

Figure 9: Effect of gasification temperature on water gas ratio: Char800, steam supply rate $0.05 \mathrm{~g} / \mathrm{min} / \mathrm{g}$

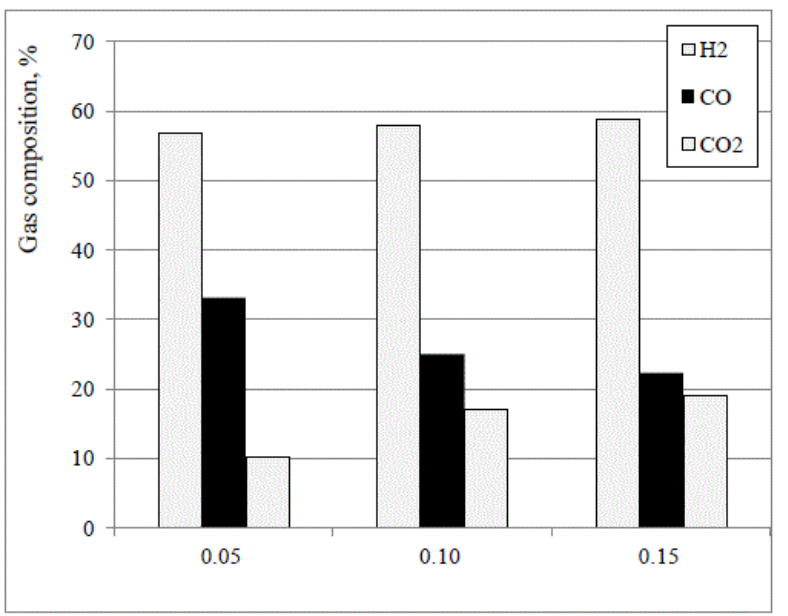

Figure 10: Effect of steam supply rate on water gas production: gasification of Char 800 at $900^{\circ} \mathrm{C}$.

\begin{tabular}{|l|l|l|l|}
\hline Steam supply, $\mathbf{m l} / \mathbf{m i n} / \mathbf{g}$ of char & $\mathbf{0 . 0 5}$ & $\mathbf{0 . 1 0}$ & $\mathbf{0 . 1 5}$ \\
\hline $\mathrm{HHV}$ of water gas, $\mathbf{~ M J} / \mathrm{m}^{3}$ & 13.07 & 11.82 & 11.77 \\
\hline Gas yield, $\mathbf{~ m}^{3} / \mathbf{k g}$ & 4.83 & 4.95 & 4.84 \\
\hline $\mathrm{H}_{2}$ & 2.75 & 2.87 & 2.82 \\
\hline $\mathrm{CO}$ & 1.60 & 1.24 & 1.21 \\
\hline $\mathrm{CH}_{4}$ & 0.00 & 0.00 & 0.00 \\
\hline $\mathrm{CO}_{2}$ & 0.49 & 0.84 & 0.81 \\
\hline
\end{tabular}

Table 4: Effect of steam supply on water gas properties 
Thus, the specific lower heating value increased and the total gas yield decreased when the steam flow rate was increased. Li, et al. [33] also indicated that with municipal solid waste, the $\mathrm{CO}$ yield decreased and the $\mathrm{H}_{2}$ and $\mathrm{CO}_{2}$ yields increased with an increase in the mass ratio of the steam to the biomass. Therefore, it is possible that this effect of the steam supply rate may be observed for all types of biomass samples.

\section{Conclusion}

To evaluate kenaf as a second step gasification resource, carbonization of kenaf to produce char and gasification of the char were performed using a small laboratory system. Carbonization of the kenaf from 600 to $1000^{\circ} \mathrm{C}$ produced suitable chars as the source for steam gasification. The gasification of these kenaf chars produced clean hydrogen-rich gases without the formation of any byproducts. On the other hand, carbonization of kenaf at $400^{\circ} \mathrm{C}$ yielded insufficient char that contained raw chemical components and generated hydrocarbons and tar-like materials during the gasification process. Importantly, the wood gas from the carbonization step had a sufficient $\mathrm{HHV}$ for use as a fuel for heating the gasifier. In the gasification of the chars, notably, a lower gasification temperature induced the water-gas shift reaction, which led to a change in the water gas composition. Raising the gasification temperature increased the specific $\mathrm{HHV}$ and decreased the gas yield. The specific HHVs were 11, 12, and $13 \mathrm{MJ} / \mathrm{m}^{3}$ for gasification reactions run at 800,900 , and $1000^{\circ} \mathrm{C}$, respectively. For all of these gasification temperatures, the $\mathrm{H}_{2}$ concentration in the water gases was greater than $58 \%$, and the $\mathrm{H}_{2} / \mathrm{CO}$ ratios ranged from 1.8 to 3.0. Increasing the steam supply rate decreased the specific $\mathrm{HHV}$ and the $\mathrm{CO}$ yield, while the $\mathrm{H}_{2}$ and $\mathrm{CO}_{2}$ yields increased. In these cases, therefore, the water-gas shift reaction played an important role.

\section{References}

1. Bridgwater AV (2003) Renewablefuels and chemicals by thermal processing of biomass. Chem Eng J 91: 87-102.

2. Umeki K, Namioka T, Yosikawa K (2012) The effect of steam on pyrolysis and char reactions behavior during rice straw gasification. Fuel Processing Technology 94:53-64.

3. Cetin E, Gupta B, Moghtaderi B (2005) Effect of pyrolysis and heating rate on radiate pine char structure and apparent gasification reactivity. Fuel 84:1328-1334.

4. Kim K, Kim Y, Yang C, Moon J, Kim B, et al. (2013) Long-term operation of biomass-to-liquid systems coupled to gasification and Fischer-Tropsch processes for biofuel production. Bioresource Technology 127:391-399.

5. Wang L, Weller CL, Jones DD, Hanna MA (2008) Contemporary issues in thermal gasification of biomass and its application to electricity and fuel production. Biomass Bioenergy 32: 573-581.

6. Kawamoto K, Wu W, Kuromachi H (2009) Development of gasification and reforming technology using catalyst at lower temperature for effective energy recovery: hydrogen recovery using waste wood. J Environ Eng 4:409-421.

7. Mermoud F, Salvador S, Van de Steene L, Golfier F (2006) Influence of pyrolysis heating on the steam gasification rate of large wood char particles. Fuel 85:1473-1482.

8. Sun Q, Yu S, Wang F, Wang J (2011) Decomposition and gasification of pyrolysis volatiles from pine wood through a bed of hot char. Fuel 90:1041-1048.

9. Rath J, Staudinger G (2001) Cracking reaction of tar from pyrolysis of spruce wood. Fuel 80: 1379-1389.
10. Devil L, Ptansinski KJ, Jansen FJJG, (2003) A review of the primary measures for tar elimination in biomass gasification process. Biomass Bioenergy 24:125-140.

11. Li XT, Grace JR, Lim CJ, Watkinson AP, Chen HP, et al. (2004) Biomass gasification in a circulating fluidized bed. Biomass Bioenergy 26:171-193.

12. Han J, Kim H (2008) The reduction and control technology of tar during biomass gasification/pyrolysis: an overview. Renew Sust Energy Rev 12:397-416.

13. Sulk J, Stojdl J, Richter M, Popelka J, Svoboda K, Smetana J, Vacek J, Skoblja S, Buryan P (2012) Biomass waste gasification -Can be the two step process suitable for tar reduction and power generation. Waste Management 32:692-700.

14. Zwart RWR (2009) Gas cleaning downstream biomass gasification status report, Report ECN Petten, ECN-08-078, Netherland.

15. Zhang Y, Ashizawa M, Kajitani S, Miura K (2008) Proposal of a semiempirical kinetic model to reconcile with gasification reactivity profiles of biomass chars. Fuel 87:475-481.

16. Cetin E, Moghtaderi B, Gupta B, Wall TF (2004) Influence of pyrolysis conditions on the structure and gasification reactivity of biomass char. Fuel 83: 2139-2150.

17. Klose W, Wolki M (2005) On the intrinsic reaction rate of biomass char gasification with carbondioxide and steam. Fuel 84: 885-892.

18. Roberts DG, Harris DJ (2007) Char gasification in mixtures of $\mathrm{CO} 2$ and H2O: Competition and inhibition. Fuel 86: 2672-2678.

19. Nilsson S, Gomez-Barea A, Cano DF (2012) Gasification reactivity of char from dried sewage sludge in a fluidized bed. Fuel 92: 346-353.

20. Teixeira G, Van den Steen L, Martin E, Gelix F, Salvador S (2012) Gasification of char form wood pellets and from wood chips: Textural properties and thermochemical conversion along a continuous fixed bed. Fuel 102: 514-524.

21. Montesions FM, Cordero T, Mirasol JR, Rodriguea JJ (2002) CO2 and steam gasification of a grapefruit skin char. Fuel 81: 423-429.

22. Matsumoto K, Takeno K, Ichinose T, OgiT, Nakanishi M (2009) Gasification reaction kinetics on biomass char obtained as a by-product of gasification in an Entrained -flow gasifier with steam and oxygen at 900-1000 ${ }^{\circ} \mathrm{C}$. Fuel 88: 519-527.

23. Haykiri-Acma H, Yaman S, Kucukbayrac S (2006) Gasification of biomass chars in steam nitrogen mixture. Energy Convers Manage 47: 1004-1013.

24. Wolfgang K, Michael W (2005) On the intrinsic reaction rate of biomass char gasification with carbon dioxide and steam. Fuel 84:885-892.

25. Fermoso J, Stevanov C, Moghtaderi B, Arias B, Pevida C, et al. (2009) High-pressure gasification reactivity of biomass chars produced at different temperature. J Anal Appl Pyrolysis 85: 287-293.

26. Chaudhari ST, Dalai AK, Bakhshi NN (2003) Production of hydrogen and/or syngas $(\mathrm{H} 2+\mathrm{CO})$ via steam gasification of biomass-derived chars. Energy Fuels 17: 1062-1067.

27. Yan F, Lio S-Y, Hu Z-Q, Xiao B, Cheng G (2010) Hydrogen-rich gas production by steam gasification of char from biomass fast pyrolysis in a fixed-bed rector: Influence of temperature and steam on hydrogen yield and syngas composition. Bioresouces Technology 101: 5633-5637.

28. Danalatos NG, Archontoulis SV (2010) Growth and biomass productivity of kenaf (Hibiscus cannabinusL.) under different agricultural inputs and management practices in central Greece. Industrial Crops and Products: 32231-32240.

29. Zhou Z, Lin X, Wu C, Ma L (2009) Research on the gasification characteristics of the industrial residues of kenaf. Proceedings of ISES world congress: 2397-2399.

30. Mitsuyoshi Y, Madoka N, Keko H, Tatsuro O, Akira S (2002) Termiticidal activity of wood vinegar, its components and their homologues. Journal of Wood Science48: 338-342.

31. Yasuo K, Yosihito U (2010) Conversion of $\mathrm{CO} 2$ to $\mathrm{CO}$ with char. Proceedings of Renewable Energy 2010, Yokohama: P-Bm-17. 
Citation: Kojima Y, Kato Y, Yoon SL, Lee MK (2014) Kenaf as a Bioresource for Production of Hydrogen-rich Gas. Agrotechnol 3: 1000125. doi: 10.4172/2168-9881.1000125

Page 8 of 8

32. Voulgaridis E, Passialis C, Grigoriou A (2000) Anatomical characteristics and properties of kenaf stem (Hibiscus cannabinus). IAWA Journal 21: 435-442.

33. 33. Li J, Liao S, Dan W, Jia K, Zhou X (2012) Experimental study on catalytic steam gasification of municipal solid waste for bioenergy production in a combined fixed bed reactor. Biomass and Bioenergy 46: 174-180. 